\title{
Developing a measure to assess motivation and self-efficacy in anorexia nervosa using the Theory of Planned Behaviour
}

\author{
Lisa Dawson ${ }^{*}$, Barbara Mullan², Paul Rhodes ${ }^{1}$, Stephen Touyz ${ }^{1}$ \\ From 2014 ANZAED Conference: Driven Bodies Driven Brains \\ Fremantle, Australia. 22-23 August 2014
}

Motivation in anorexia nervosa (AN) has been almost exclusively measured using the Transtheoretical Model of Change, despite criticisms of this model. In other areas of psychology, alternative models have been proposed to explain motivation. In Health Psychology, the Theory of Planned Behaviour (TPB) is a widely used and supported model. The aim of the current study was to determine the appropriateness of the TPB for understanding intentions to recover from AN and to develop a purpose-designed TPB measure to assess this. Thirteen adults who had recovered from $\mathrm{AN}$ were interviewed to elicit the salient beliefs underlying the three components of the TPB (attitudes, subjective norms, perceived behavioural control). Data from interviews revealed that beliefs and attitudes about recovery were compatible with the TPB and a 27-item self-report measure was developed. The TPB appears to be a good fit, from a theoretical perspective, for determining intentions to change in AN. The findings add to a growing body of research examining motivation in $\mathrm{AN}$ and provide further insight into how this can be measured.

This abstract was presented in the Assessment stream of the 2014 ANZAED Conference.

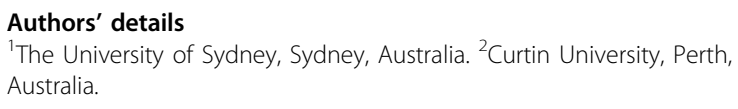

Published: 24 November 2014

* Correspondence: lisa.dawson@sydney.edu.au

${ }^{1}$ The University of Sydney, Sydney, Australia

Full list of author information is available at the end of the article
doi:10.1186/2050-2974-2-S1-046

Cite this article as: Dawson et al:: Developing a measure to assess motivation and self-efficacy in anorexia nervosa using the Theory of Planned Behaviour. Journal of Eating Disorders 2014 2(Suppl 1):046.
Submit your next manuscript to BioMed Central and take full advantage of:

- Convenient online submission

- Thorough peer review

- No space constraints or color figure charges

- Immediate publication on acceptance

- Inclusion in PubMed, CAS, Scopus and Google Scholar

- Research which is freely available for redistribution
() Biomed Central 